\title{
Diurnal variation of methane emission from paddy fields at different growth stages of rice cultivation in Taiwan
}

\author{
Shang-Shyng Yang *, Hsiu-Lan Chang \\ Department of Agricultural Chemistry, National Taiwan University, Taipei, Taiwan 10617
}

Received 29 June 1998; received in revised form 26 February 1999; accepted 5 May 1999

\begin{abstract}
Paddy fields are one of the major anthropogenic sources of methane emission. Methane emission from paddy fields can vary with the growth stages of the rice (Oryza sativa L.) plant and daily environmental conditions. There are two crop seasons in Taiwan, the first crop season is from low to high temperature (February-June), and the second crop season is reversed (August-December). The objective of this study was to investigate the effect of growth stages and daily environmental conditions on methane emission from a paddy field at the Agricultural Experimental Station of National Taiwan University in Taipei $\left(25^{\circ} 1^{\prime} 30^{\prime \prime} \mathrm{N}, 121^{\circ} 31^{\prime} 30^{\prime \prime} \mathrm{E}\right)$. Methane emission rate was high at the rice booting and the flowering stages and low at the transplanting and the ripening stages in the first crop season; while it was high at the transplanting and the active tillering stages and low from the booting to the ripening stages with intermittent irrigation system. Continuous flooding treatment significantly enhanced methane emission at the flowering and the ripening stages in the first crop season. Methane emission rate was high from 12 a.m. to 3 p.m., and low from 2 to 5 a.m. Methane emission showed high correlation coefficient with air temperature, and low correlation with light intensity. Methane emission in the second crop season (13.7-28.9 $\left.\mathrm{g} \mathrm{m}^{-2}\right) \mathrm{was}$ about 2-5-fold higher than that in the first crop season $\left(2.6-11.7 \mathrm{~g} \mathrm{~m}^{-2}\right)$. This phenomenon was reversed in continuous flooding treatment. Estimated total methane emission from Taiwan paddy fields in 1996 was between 27,352 and 69,060 Mg with intermittent irrigation system, which was lower than $231,147 \mathrm{Mg}$ calculated by the IPCC method with continuous flooding treatment. Intermittent irrigation is a useful approach to reduce emissions in paddy fields. (C1999 Elsevier Science B.V. All rights reserved.
\end{abstract}

Keywords: Diurnal variation; Methane emission; Paddy field; Temperature; Redox potential

\section{Introduction}

Methane currently has a globally averaged mixing ratio of about $1.72 \mathrm{mg} \mathrm{kg}^{-1}$ (vol.) in the troposphere. Methane is produced by a group of strictly anaerobic bacteria in highly chemically reduced habitats such

\footnotetext{
* Corresponding author. Tel.: +886-2-23621519; fax: +886-223679827

E-mail address: ssyang@ccms.ntu.edu.tw (S.-S. Yang)
}

as rice paddies, swamps, sludge digesters, rumens, and sediments (Banker et al., 1995; Yang and Chang, 1997; Yang et al., 1998). Global annual methane emission from rice fields were estimated to range from 25 to $100 \mathrm{Tg}$ which contributed $10-30 \%$ of global methane emission (Crutzen, 1991; IPCC, 1995). Temperature, organic matter content, fertilizer application, rice plant, $\mathrm{pH}$, redox potential, soil type and water management are the major factors affecting methane emission (Sass et al., 1991; Adhya et al., 1994; Banker 
et al., 1995; Buendia et al., 1998; Yang and Chang, 1998). There is a positive linear correlation between methane production and incubation temperature from 15 to $37^{\circ} \mathrm{C}$, and a negative linear correlation between 37 and $50^{\circ} \mathrm{C}$ (Yang and Chang, 1998). Supplementation of rice straw, green manure and compost has a stimulating effect on methane production (Buendia et al., 1998; Yang and Chang, 1998).

In Taiwan, Yang et al. (1994) and Yang and Chang (1997) showed that methane emission from paddy rice, in pot experiments, with continuous flooding was high at the active tillering, flowering and ripening stages in the first crop season. It was also high at the transplanting, active tillering and booting stages in the second crop season due to the high temperature and active growth of the rice plant.

Rice is the major crop in Taiwan and there are two crop seasons. The cultivated areas were 182,807 ha and 164,955 ha for the first and second crop seasons in 1996, respectively. This cropping system is different from the single crop season in Japan, Korea, Texas and Beijing. In addition, intermittent irrigation is used in Taiwan for saving the water resource, while a continuous flooding system is the practice in other countries. Diurnal variation of methane emission from rice paddy with continuous flooding treatment had been studied in several locations (Buendia et al., 1998). Methane emission pattern in Taiwan was different from the other areas because of the rice cropping system and irrigation management. This work reports the diurnal variation of methane emission from a paddy field with two crop seasons and two irrigation systems at different growth stages from the second crop season 1994 to the first crop season 1996 in Taiwan.

\section{Materials and methods}

\subsection{Experimental site}

A paddy field (about 1.0 ha) at the Agricultural Experimental Station of National Taiwan University located in Taipei $\left(25^{\circ} 1^{\prime} 30^{\prime \prime} \mathrm{N}, 120^{\circ} 31^{\prime} 30^{\prime \prime} \mathrm{E}\right)$, Taiwan was selected. The soil is a fine-loamy mixed, Hyperthermic, Typic Haplanthrept (TARI, 1978; Soil Survey Staff, 1998). Some soil properties are as follows: $\mathrm{pH} 5.6 \pm 0.1$, organic matter $28.4 \pm 0.4 \mathrm{~g} \mathrm{~kg}^{-1}$ (dry weight), total nitrogen $1.73 \pm 0.2 \mathrm{~g} \mathrm{~kg}^{-1}$ (dry weight), and sand : clay $:$ silt $=453: 201: 346 \mathrm{~g} \mathrm{~kg}^{-1}$. All the experiments were performed in tetraplicates.

\subsection{Rice and fertilizer}

Tainung No. 67 a Japonica rice (Oryza sativa L.) was used in the study. Taifei No. $1(\mathrm{~N}: \mathrm{P}: \mathrm{K}=20: 2.2$ : 8.3, wt.\%) (Taiwan Fertilizer Corporation, Taiwan) was applied as basal fertilizer $\left(400 \mathrm{~kg} \mathrm{ha}^{-1}\right)$ before rice transplanting. Urea $\left(100 \mathrm{~kg} \mathrm{ha}^{-1}\right)$ and ammonium sulfate $\left(100-500 \mathrm{~kg} \mathrm{ha}^{-1}\right)$ were used as the first and the second topdressing fertilizers at the active tillering and the booting stages, respectively.

Rice field operations in the second crop season (1994) were as follows: plowing on 25 July, flooding on 1 August, transplanting on 11 August, intermittent irrigation from 14 October to 29 November 1994, and rice plant harvesting on 5 January 1995 (total cultivation period was 147 days). In the first crop season (1995), rice field operations were as follows: plowing on 20 February, flooding on 2 March, transplanting on 14 March, intermittent irrigation from 15 April to 2 July, and rice plant harvesting on 21 July 1995 (total cultivation period was 129 days). In the second crop season (1995), rice field operations were as follows: plowing on 15 July flooding on 21 July, transplanting on 31 July, intermittent irrigation from 5 October to 23 November, and rice plant harvesting on 13 December, 1995 (total cultivation period was 136 days). For the first crop season (1996) the field operations were as follows: plowing on 19 February, flooding on 4 March, transplanting on 15 March, continuous flooding until 20 July (intermittent irrigation from 20 April to 20 July), and rice plant harvesting on 5 August 1996 (total cultivation period was 152 days). Rice straw was removed from the field after each harvest.

\subsection{Diurnal variation of methane emission and environmental conditions}

Diurnal variations of methane emission, light intensity, air, water and soil temperatures, water and soil $\mathrm{pHs}$, and soil redox potential were investigated in the test paddy field. Six sampling stages, during the flooding to transplanting, active tillering, booting, flowering, ripening and off-crop, were chosen in each crop season. 


\subsection{Gas sampling chamber}

Gas samples were collected using a home-made acrylic chamber (length, $40 \mathrm{~cm}$; width, $40 \mathrm{~cm}$; and height, $65 \mathrm{~cm}$; about 961 of volume) that was equipped with an electronic fan, a thermometer and a sampling hole. In the later growth stage of the paddy rice, a two-layer acrylic chamber was used (height, $130 \mathrm{~cm}$; volume about 1921). Four hills (spacing of hill was $24 \mathrm{~cm} \times 27 \mathrm{~cm}$ ) were measured, and four chambers were used in each measurement (Chang and Yang, 1997).

\subsection{Gas sampling period and method}

Methane flux methodology followed the recommendation of previous studies (Yang et al., 1994; Buendia et al., 1998; Yang and Chang, 1998). Gas was sampled every $3 \mathrm{~h}$ on the first day and twice a day, at 5 a.m. and 2 p.m., on the second and the third day in each growth stage. Gas sample was collected at 0 , 30 and $60 \mathrm{~min}$ accumulative time using the gas dilution method. Air temperature increased $2-3^{\circ} \mathrm{C}$ during $1 \mathrm{~h}$ closure in the day time, and it increased $0-0.5^{\circ} \mathrm{C}$ at night. Five $\mathrm{ml}$ of gas was withdrawn by a $10 \mathrm{ml}$ disposable plastic syringe from a $12 \mathrm{ml}$ serum bottle, that had been sealed with a butyl rubber stopper and flushed with oxygen-free nitrogen. Then, $5 \mathrm{ml}$ of the gas sample was injected into a serum bottle (Chang and Yang, 1997).

\subsection{Methane emission}

Methane emission was determined at a $0.5 \mathrm{~h}$ intervals for $1.0 \mathrm{~h}$ by examining the changes of methane concentration in the acrylic chamber. The gas sample was injected into a Shimadzu 14A gas chromatograph with a glass column $(0.26 \mathrm{~mm} \times 2 \mathrm{~m})$ which was packed with Porapak Q (80/100 mesh). The column temperature was set at $100^{\circ} \mathrm{C}$, and the injection and the detector temperatures were set at $130^{\circ} \mathrm{C}$. Methane concentration was calculated with a standard curve from 0.1 to $1000 \mathrm{mg} \mathrm{kg}^{-1}$ (vol.) (Chang and Yang, 1997).

\subsection{Estimation of methane emission}

Methane emission from paddy field was calculated by the experimental data and estimated by the follow- ing equation (Rolston, 1986):

$f=\left(\frac{V}{A}\right)\left(\frac{\Delta C}{\Delta t}\right)$

where $f$ is equal to methane emission rate $\left(\mathrm{mg} \mathrm{m}^{-2} \mathrm{~h}^{-1}\right)$, $V$ is equal to volume of chamber above soil $\left(\mathrm{m}^{3}\right), A$ equal to cross-section of chamber $\left(\mathrm{m}^{2}\right), \Delta C$ equal to concentration difference between zero and $t$ times $\left(\mathrm{mg} \mathrm{cm}^{-3}\right)$, and $\Delta t$ equal to time duration between two sampling periods (h). Methane emission from paddy soil was calculated from the summation of methane emission in five growth stages of rice plants.

\subsection{Analytical methods}

Light intensity was measured with Toshiba SPI-5 photometer. Soil $\mathrm{pH}(10 \mathrm{~cm}$ depth) or water $\mathrm{pH}$ was determined directly in the field, or on $1: 1(\mathrm{w} / \mathrm{w})$ soil to water suspension with $\mathrm{pH}$ meter (Mode Sentron 2001) (Nelson and Sommers, 1982). Redox potential was measured with a Hanna No. 081-854 potential meter (Code HI 8424) under 5-20 cm depth of topsoil using the Pt electrode after a 20-25 min equilibrium with the soil (Yang and Chang, 1997). Air, water and soil temperatures were determined with a thermometer. Experiments were carried out to obtain four measurements, and flux data subjected to analysis of variance and Duncan's multiple range test $(p=0.05)$ using the Statistical Analysis System (SAS Institute, 1988).

\section{Results}

\subsection{Diurnal variation of environmental conditions during rice cultivation}

Light intensity was high from 10 a.m. to 2 p.m. and low from 7 p.m. to 5 a.m. In the first crop season, light intensity ranged from 70,000 to $90,000 \mathrm{~lx}$ at the ripening and the flowering stages, and between 40,000 and 70,000 $\mathrm{lx}$ at the transplanting and the active tillering stages. While in the second crop season, light intensity ranged from 75,000 to $100,000 \mathrm{~lx}$ at the transplanting and the active tillering stages, and between 25,000 and 75,000 $1 \mathrm{x}$ at the ripening and the flowering stages. There were significant differences of light intensity among these five growth stages of rice in both crop seasons (data not shown). 
Table 1

Methane emission from paddy soil at different growth stages of rice plants over several crop seasons ${ }^{\mathrm{a}}$

\begin{tabular}{|c|c|c|c|c|c|}
\hline \multirow[t]{2}{*}{ Stage } & \multicolumn{3}{|c|}{ First crop season } & \multicolumn{2}{|c|}{ Second crop season } \\
\hline & 1995 & 1996 cont. $^{\text {b }}$ & 1996 inter. $^{\text {b }}$ & 1994 & 1995 \\
\hline \multicolumn{6}{|l|}{ Emission rate $\left(\mathrm{mg} \mathrm{m}^{-2} \mathrm{~h}^{-1}\right)$} \\
\hline \multirow[t]{2}{*}{ Transplanting } & $0.21 \pm 0.05$ & $0.21 \pm 0.07$ & $0.21 \pm 0.10$ & $11.80 \pm 3.50$ & $9.52 \pm 2.22$ \\
\hline & $0.83 \pm 0.20^{\mathrm{c}}$ & $1.15 \pm 0.23^{\mathrm{c}}$ & $1.13 \pm 0.13^{c}$ & $30.50 \pm 8.15^{\mathrm{a}}$ & $24.45 \pm 5.67^{\mathrm{a}}$ \\
\hline \multirow[t]{2}{*}{ Active tillering } & $0.31 \pm 0.06$ & $2.01 \pm 0.89$ & $1.97 \pm 0.73$ & $0.93 \pm 0.35$ & $10.01 \pm 2.29$ \\
\hline & $0.88 \pm 0.08^{\mathrm{c}}$ & $5.94 \pm 1.62^{b c}$ & $5.97 \pm 1.41^{\mathrm{bc}}$ & $3.13 \pm 1.52^{\mathrm{c}}$ & $27.08 \pm 6.06^{\mathrm{a}}$ \\
\hline \multirow[t]{2}{*}{ Booting } & $0.85 \pm 0.13$ & $13.33 \pm 3.39$ & $3.09 \pm 1.23$ & $0.36 \pm 0.12$ & $5.41 \pm 1.18$ \\
\hline & $1.49 \pm 0.20^{c}$ & $29.53 \pm 6.74^{\mathrm{a}}$ & $7.34 \pm 1.69^{\mathrm{b}}$ & $0.92 \pm 0.26^{\mathrm{c}}$ & $6.87 \pm 1.35^{\mathrm{b}}$ \\
\hline \multirow[t]{2}{*}{ Flowering } & $1.02 \pm 0.19$ & $10.13 \pm 1.90$ & $1.52 \pm 0.32$ & $0.06 \pm 0.02$ & $3.77 \pm 1.05$ \\
\hline & $2.83 \pm 0.77^{\mathrm{c}}$ & $20.92 \pm 6.28^{\mathrm{a}}$ & $2.61 \pm 0.40^{\mathrm{c}}$ & $0.13 \pm 0.04^{\mathrm{c}}$ & $5.92 \pm 3.04^{\mathrm{bc}}$ \\
\hline \multirow[t]{2}{*}{ Ripening } & $0.21 \pm 0.05$ & $4.96 \pm 2.12$ & $0.20 \pm 0.12$ & $0.01 \pm 0.01$ & $0.01 \pm 0.00$ \\
\hline & $0.54 \pm 0.19^{c}$ & $10.89 \pm 2.84^{\mathrm{b}}$ & $0.56 \pm 0.15^{\mathrm{c}}$ & $0.08 \pm 0.02^{\mathrm{c}}$ & $0.03 \pm 0.01^{\mathrm{c}}$ \\
\hline Seasonal total emission $\left(\mathrm{g} \mathrm{m}^{-2}\right)$ & $2.55 \pm 0.16^{\mathrm{c}}$ & $32.65 \pm 10.17^{\mathrm{a}}$ & $11.70 \pm 1.88^{\mathrm{b}}$ & $13.73 \pm 1.70^{\mathrm{b}}$ & $28.85 \pm 3.25^{\mathrm{a}}$ \\
\hline Average emission rate $\left(\mathrm{mg} \mathrm{m}^{-2} \mathrm{~h}^{-1}\right)$ & $0.76 \pm 0.05^{\mathrm{c}}$ & $9.72 \pm 3.03^{\mathrm{a}}$ & $2.74 \pm 0.54^{\mathrm{bc}}$ & $4.85 \pm 0.59^{\mathrm{b}}$ & $9.54 \pm 1.07^{\mathrm{a}}$ \\
\hline
\end{tabular}

${ }^{a}$ Rice cultivation was described in the text. Mean \pm SD $(n=4)$, in the same row that do not share the same alphabetic superscript are significantly different $5 \%$ level according to Duncan's multiple range test. The data showed range of methane emission in the early morning (6 a.m., low value) and at the noon ( 2 a.mp.m., high value) in each measurement.

${ }^{\mathrm{b}}$ Both continuous flooding treatment and intermittent irrigation system were used in the first crop season 1996.

Daily air temperature was high from 11 a.m. to 2 p.m., and low from 2 to 5 a.m. Air temperature was $10-25^{\circ} \mathrm{C}, 20-31^{\circ} \mathrm{C}, 21-32^{\circ} \mathrm{C}, 21-33^{\circ} \mathrm{C}$, and $26-37^{\circ} \mathrm{C}$ at the transplanting, active tillering, booting, flowering and ripening stages, respectively in the first crop season. In the second crop season, it was $26-38^{\circ} \mathrm{C}, 23-$ $36^{\circ} \mathrm{C}, 21-30^{\circ} \mathrm{C}, 18-25^{\circ} \mathrm{C}$, and $13-21^{\circ} \mathrm{C}$, respectively.

The fluctuation of water and soil temperatures was narrower than air temperature. Water and soil have high heat capacity that adjusted the temperature change. Soil temperature was the highest at the early morning in the winter season (December-February), while air temperature was the highest at the mid-day in the summer season (July-September). Temperatures had also significant differences among these five rice growth stages in both crop seasons (Fig. 1).

Soil $\mathrm{pH}$ fluctuation was not significant during the day time, except at the transplanting stage. Due to the high temperature, the application of organic matter and the active microbial metabolites at the transplanting stage in the second crop season, soil and water pHs were low at this stage for the accumulation of organic acids (data not shown).

Redox potential was low at the flooding and the transplanting stages (early growth period), $-100-250 \mathrm{mV}$, whereas the value increased gradually at the flowering and the ripening stages with the intermittent irrigation, $-50-100 \mathrm{mV}$ (data not shown).

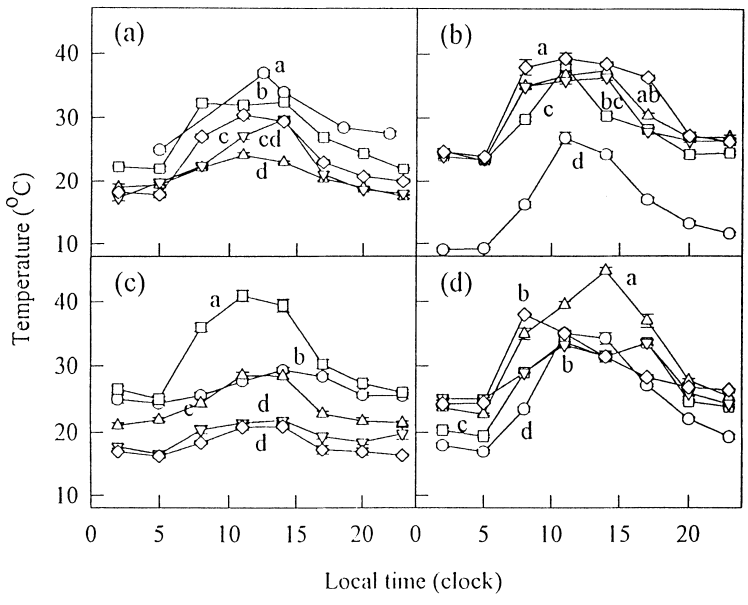

Fig. 1. Diurnal variation of air temperature of paddy field during during the rice growing season. (a) The second crop season 1994, (b) the first crop season 1995, (c) the second crop season 1995, (d) the first crop season 1996. Curves in the figure that do not share the same alphabetic mark are significantly different at 5\% level according to Duncan's multiple range test. $\bigcirc-\bigcirc$, transplanting stage; $\square-\square$, active tillering stage; $\triangle-\triangle$, booting stage; $\nabla-\nabla$, flowering stage; $\diamond \smile$, ripening stage.

\subsection{Methane emission at different growth stages}

Methane emission at different growth stages of the rice plant is shown in Table 1. Methane emission rate was high from the active tillering to the flowering 
Table 2

The correlation coefficient between methane emission rate at different rice ${ }^{\mathrm{a}}$ growth stages and temperature of air, water, and soil

\begin{tabular}{|c|c|c|c|c|c|c|c|c|c|c|c|c|}
\hline \multirow{2}{*}{$\begin{array}{l}\text { Crop season growth } \\
\text { stage temperature }\end{array}$} & \multicolumn{3}{|c|}{ Second crop 1994} & \multicolumn{3}{|c|}{ First crop 1995} & \multicolumn{3}{|c|}{ Second crop 1995} & \multicolumn{3}{|c|}{ First crop $1996^{\mathrm{b}}$} \\
\hline & Air & Water & Soil & Air & Water & Soil & Air & Water & Soil & Air & Water & Soil \\
\hline Transplanting & $0.92^{\mathrm{a}}$ & $0.89^{\mathrm{a}}$ & $0.67^{\mathrm{a}}$ & $0.83^{\mathrm{a}}$ & $0.79^{\mathrm{a}}$ & $0.48^{\mathrm{a}}$ & $0.85^{\mathrm{a}}$ & $0.82^{\mathrm{a}}$ & $0.69^{\mathrm{a}}$ & $0.72^{\mathrm{ab}}$ & $0.71^{\mathrm{a}}$ & $0.55^{\mathrm{c}}$ \\
\hline Active tillering & $0.52^{\mathrm{b}}$ & $0.52^{\mathrm{b}}$ & $0.41^{b}$ & $0.58^{\mathrm{b}}$ & $0.59^{\mathrm{b}}$ & $0.47^{\mathrm{a}}$ & $0.69^{\mathrm{b}}$ & $0.80^{\mathrm{a}}$ & $0.49^{\mathrm{c}}$ & $0.69^{\mathrm{b}}$ & $0.60^{\mathrm{b}}$ & $0.62^{\mathrm{b}}$ \\
\hline Booting & $0.44^{\mathrm{c}}$ & $0.47^{\mathrm{c}}$ & $0.35^{\mathrm{c}}$ & $0.44^{\mathrm{c}}$ & $0.43^{\mathrm{c}}$ & $0.37^{\mathrm{c}}$ & $0.46^{\mathrm{c}}$ & $0.66^{\mathrm{c}}$ & $0.61^{\mathrm{ab}}$ & $0.78^{\mathrm{a}}$ & $0.76^{\mathrm{a}}$ & $0.73^{\mathrm{a}}$ \\
\hline Flowering & $0.41^{\mathrm{c}}$ & $0.40^{\mathrm{d}}$ & $0.27^{\mathrm{d}}$ & $0.24^{\mathrm{d}}$ & $0.17^{\mathrm{d}}$ & $0.19^{\mathrm{d}}$ & $0.23^{\mathrm{d}}$ & $0.43^{\mathrm{d}}$ & $0.42^{\mathrm{d}}$ & $0.65^{\mathrm{c}}$ & $0.56^{\mathrm{bc}}$ & $0.47^{\mathrm{d}}$ \\
\hline Ripening & $0.20^{\mathrm{e}}$ & $0.30^{\mathrm{e}}$ & $0.25^{\mathrm{e}}$ & $0.22^{\mathrm{d}}$ & $0.16^{\mathrm{d}}$ & $0.15^{\mathrm{de}}$ & $0.25^{\mathrm{d}}$ & $0.20^{\mathrm{e}}$ & $0.15^{\mathrm{e}}$ & $0.43^{\mathrm{d}}$ & $0.40^{\mathrm{d}}$ & $0.35^{\mathrm{d}}$ \\
\hline Off-crop & $0.10^{\mathrm{f}}$ & $0.11^{\mathrm{f}}$ & $0.12^{\mathrm{f}}$ & $0.15^{\mathrm{f}}$ & $0.15^{\mathrm{d}}$ & $0.11^{\mathrm{de}}$ & $0.10^{\mathrm{e}}$ & $0.12^{\mathrm{f}}$ & $0.20^{\mathrm{ef}}$ & $0.18^{\mathrm{e}}$ & $0.17^{\mathrm{e}}$ & $0.17^{\mathrm{e}}$ \\
\hline
\end{tabular}

\footnotetext{
${ }^{\text {a }}$ Rice cultivation was described in the text. Mean $(n=4)$, in the same row that do not share the same alphabetic superscript are significant different 5\% level according to Duncan's multiole range test.
}

${ }^{\mathrm{b}}$ The data were calculated with continuous flooding treatment.

stages while it was low at the transplanting and the ripening stages for low temperature and high redox potential, respectively, in the first crop season with intermittent irrigation. Methane emission rate was high at the transplanting and the active tillering stages for high temperature and low redox potential, and low at the flowering and the ripening stages for low temperature and high redox potential in the second crop season. However, methane emission was also very significant during the booting to the ripening stages in the first crop season 1996 with continuous flooding. Methane emission from soil with continuous flooding was 2.8 times higher than that with intermittent irrigation in the first crop season. Total methane emission in the second crop season was 2-5-fold higher than that in the first crop season with the practice of intermittent irrigation.

\subsection{Diurnal variation of methane emission rate during rice cultivation}

\subsubsection{First crop season}

Methane emission rate was high between 12 a.m. and 3 p.m. and low at early morning. Methane emission rate increased from the transplanting stage to the flowering stage, and then decreased at the ripening stage in 1995 with intermittent irrigation (Fig. 2). The correlation coefficient between methane emission rate and temperature was high at the transplanting and the active tillering stages, and low at the flowering and the ripening stages due to the drainage management (Table 2). While in 1996 with continuous flooding, methane emission rate increased from the transplanting stage to

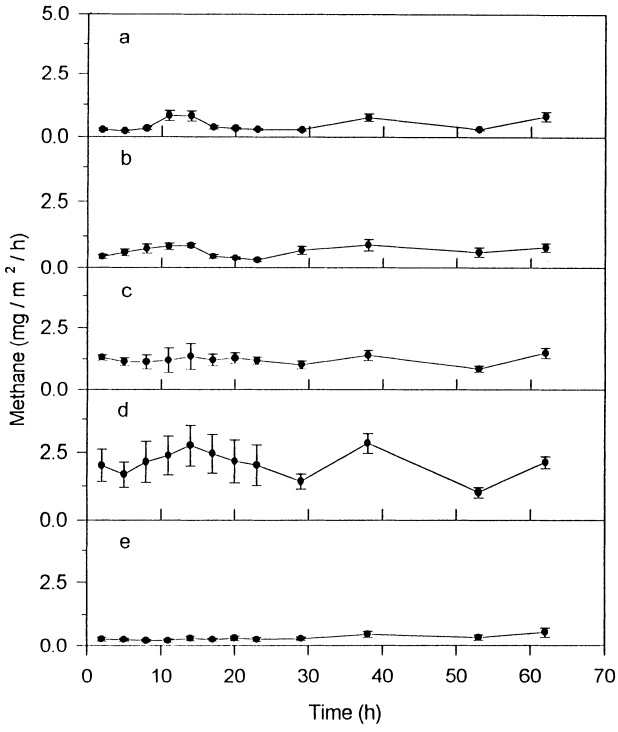

Fig. 2. Diurnal variation of methane emission rate from paddy field in the first crop season 1995 with intermittent irrigation (mean and standard deviation). The first measurement was at 2 a.m. and the last measurement was at 2 p.m. (a) Transplanting stage (6-8 March), (b) active tillering stage (1-3 May), (c) booting stage (30 May to 1 June), (d) flowering stage (1-3 July), (e) Ripening stage (17-19 July).

the flowering stage, the value decreased gradually at the ripening stage (Fig. 3). The correlation coefficient between methane emission rate and temperature was high from the transplanting to the flowering stages, and was moderate at the ripening stage (Table 2). In case of intermittent irrigation, methane emission rates in 1996 at different growth stages of rice were similar to the year 1995 . 


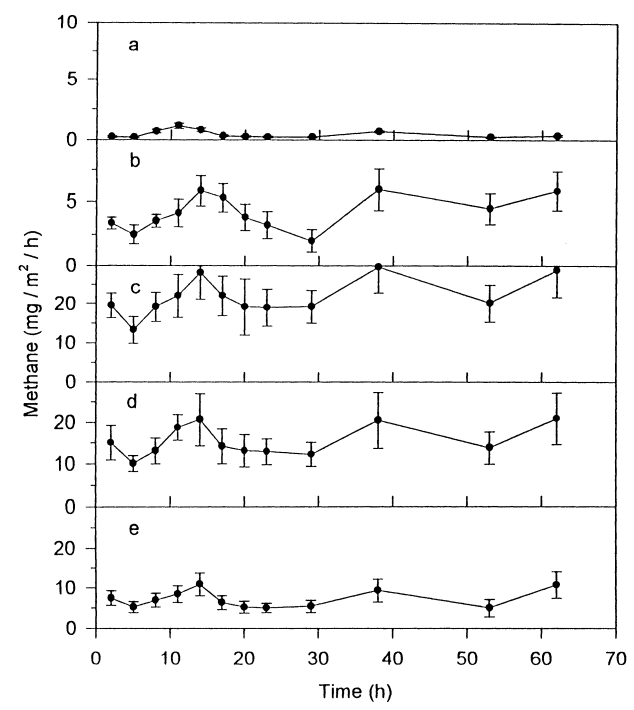

Fig. 3. Diurnal variation of methane emission rate from paddy field in the first crop season 1996 with continuous flooding (mean and atandard deviation). The first measurement was at 2 a.m. and the last measurement was at 2 p.m. (a) Transplanting stage (7-9 March), (b) active tillering stage (29 April to 1 May), (c) booting stage (4-6 June), (d) flowering stage (28-30 June), (e) ripening stage (17-19 July).

\subsubsection{Second crop season}

In 1994 with intermittent irrigation, methane emission rate was high at the transplanting and the active tillering stages for high temperature and continuous flooding, and was low at the flowering and the ripening stages for low temperature and drainage treatment (Fig. 4). The correlation coefficient between methane emission rate and temperature was high at the transplanting and the active tillering stages, and was low at the ripening stage (Table 2). In 1995, methane emission rate at different growth stages was similar to that in 1994 (Fig. 5). The correlation coefficient between methane emission rate and temperature was high at the transplanting and the active tillering stages, and was low at the flowering and the ripening stages (Table 2). From the statistical analysis, air temperature had the highest correlation coefficient with methane emission among the test temperatures.

Although soil redox potential and $\mathrm{pH}$ were very important for methane production by microbes, the correlation coefficient between methane emission rate and soil redox potential was less than 0.35 . In addition, the correlation coefficient between methane emission rate and water $\mathrm{pH}$ was less than 0.25 , and between methane emission rate and soil $\mathrm{pH}$ it was less than 0.30 . Temperature and water management were probably the major factors in methane emission from the paddy field.

\section{Discussion}

The seasonal variation of environmental conditions was very consistent from July 1994 to July 1996. Occasional rain in the summer season reduced the temperature, light intensity, and the soil redox potential. The methane emission rate, the light intensity, and the temperature were high around the mid-day, while the values were low at the early morning. Methane emission rate was also high during the mid-day in the paddy soils of Italy, India, Indonesia, Philippines, Korea and China (Schutz et al., 1989; Adhya et al., 1994; Shin et al., 1995; Buendia et al., 1998). Sass et al. (1991) indicated that methane emission from a paddy soil in Texas was strongly correlated with temperature. Yang and Chang (1998) found that methane production rate increased with temperature and had a linear relationship between 15 and $37^{\circ} \mathrm{C}$ in laboratory studies. High temperature increase the degradation of organic matter, and enhanced the production and emission of methane.

Rice has only a single crop season in Texas, Korea and Japan (Yagi and Minami, 1990; Sass et al., 1991; Shin et al., 1995), while it has two crop seasons in Taiwan. Temperature increases gradually in the first crop season in Taiwan, and it reverses in the second crop season. In addition, continuous flooding treatment was usually used in Texas and other countries, while a dry crop season and wet crop season was as in Philippines (Cicerone et al., 1983; Sass et al., 1991; Buendia et al., 1998). In Taiwan, intermittent irrigation from the late booting to the ripening stages is the practice. Neue et al. (1994) showed that methane emission rate increased rapidly after sunrise, peaked early in the afternoon, then declined gradually until they leveled off at night in Philippines. In that study, a single peak of methane emission occurred between noon to 2 p.m., and fluctuation of methane emission was very distinct from the transplanting to the panicle initiation, and from the flowering to the harvest. Less fluctuation was observed between the panicle 


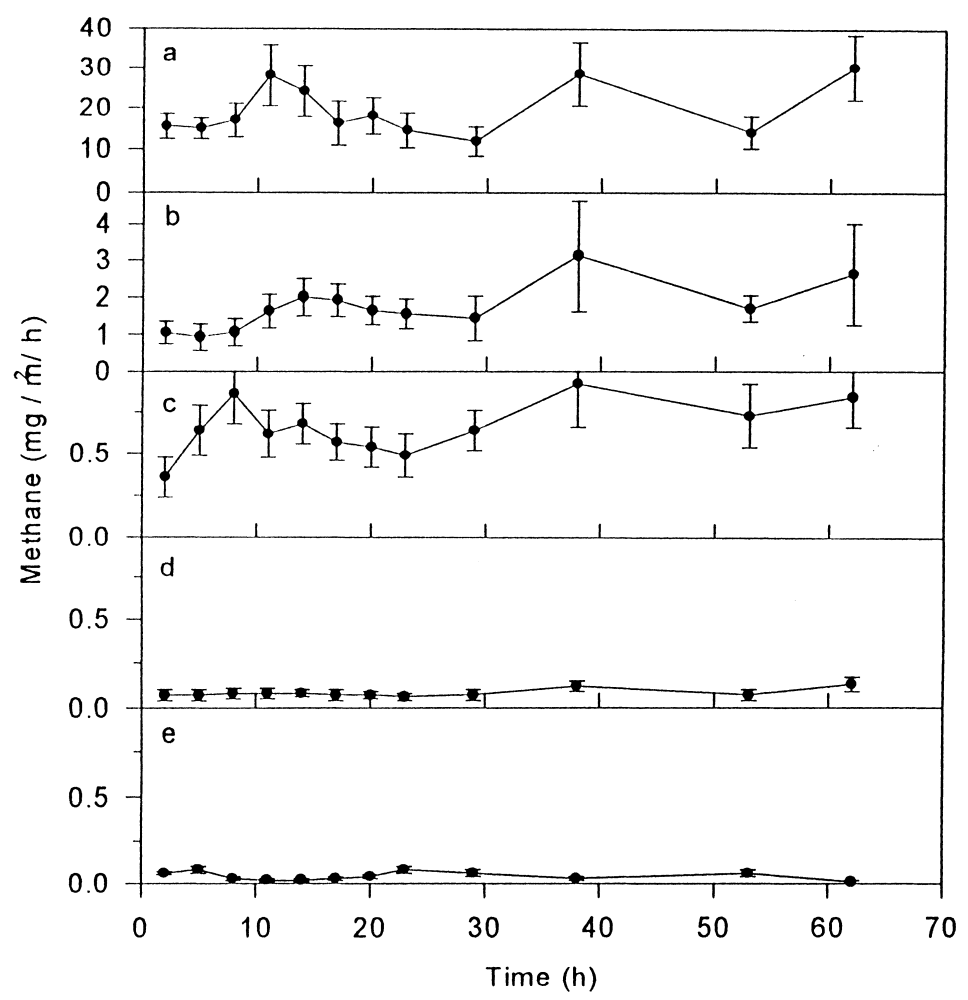

Fig. 4. Diurnal variation of methane emission rate from paddy field in the second crop season 1994 with intermittent irrigation (mean and standard deviation). The first measurement was at 2 a.m. and the last measurement was at 2 p.m. (a) Transplanting stage (11-13 August), (b) active tillering stage (15-17 September), (c) booting stage (25-27 October), (d) flowering stage (3-5 November), (e) ripening stage (6-8 December).

initiation to the flowering stage (Buendia et al., 1998). In a Beijing paddy field, methane emission exhibited two peaks, the first peak between noon to 2 p.m. and the second peak between midnight to 1 a.m.; while methane emission had three peaks from the flowering to the harvest, 2 a.m., $8-10$ a.m. and 8 p.m. (Wang and Shangguan, 1995). However, methane emission had a single peak between 2 and 4 p.m. in a Hangzhou paddy field (Buendia et al., 1998). Therefore, methane emission patterns in the present studies at different growth stages with two cropping seasons and two irrigation systems were different from those found in Taxes, Los Banos, Beijing and Hangzhou with a single cropping system and/or continuous flooding. These differences may be due to the intermittent irrigation system and the temperature change pattern.

The correlation coefficient between methane emission and light intensity was less than 0.10 in this study. A similar result was also found in a Langyang paddy soil (Yang and Chang, 1998), while it was somewhat different from that observed in Texas paddy fields (Sass et al., 1991). The annual methane emission in Texas increased with cumulative sunshine period in the paddy fields. Both the rice physiology and the soil redox potential were different between the two cultivation sites, and the effect of light intensity on methane emission was also somewhat different.

Most methanogenic bacteria grow at a $\mathrm{pH}$ range of 6.5-7.5. The optimal $\mathrm{pH}$ for methane emission ranges from 6.0 to 7.1 in paddy soil (Wang et al., 1993). In the present study, the variation of water and soil $\mathrm{pH}$ values was not significant except at the transplanting stage. Most of the values for $\mathrm{pH}$ were between 6.0 and 7.5, which were optimum for the growth of methanogenic bacteria. Methanogenic bacteria are obligately anaerobic, requiring a redox potential of about $-200 \mathrm{mV}$ or less to grow (Mah and Smith, 1981). The results of the present study showed that methane emission was 


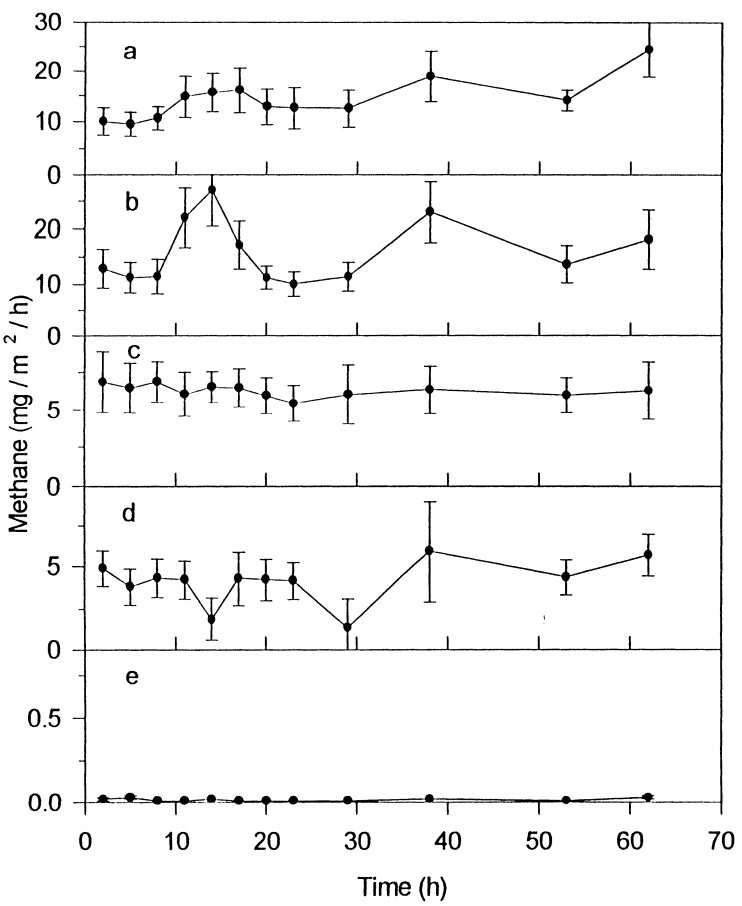

Fig. 5. Diurnal variation of methane emission rate from paddy field in the second crop season 1995 with intermittent irrigation (mean and standard deviation). The first measurement was at 2 a.m. and the last measurement was at 2 p.m. (a) Transplanting stage (24-26 August), (b) active tillering stage (3-5 October), (c) booting stage (19-21 October), (d) flowering stage (3-5 November), (e) ripening stage (29 November to 1 December).

high during the flooding to the transplanting stages at low $E_{\mathrm{h}}$, while methane emission was low at the flowering and the ripening stages at high $E_{\mathrm{h}}$ in the paddy field with intermittent irrigation. Although the latter rice growth stage had high root secretion and high metabolic activity, high $E_{\mathrm{h}}$ did not favor methane emission and reduced methane emission at the flowering and the ripening stages.

Cicerone et al. (1983) indicated that methane production at the flowering stage ranged from 76 to $92 \%$ of the total amount of methane production in California rice paddies. This percentage was higher than that found for the present study with intermittent irrigation. In the first crop season, methane emission at the flowering stage ranged from 30 to $43 \%$ of the total amount of methane production, while it was only between 1 and $13 \%$ in the second crop season. Buendia et al. (1998) found about $86 \%$ of methane was released to atmosphere from the transplanting to the panicle initiation stages in Beijing. The differences among these results are probably due to the water flooding during the cultivation period in California, as against water flooding only during the transplanting and the active tillering stages, and intermittent irrigation from the booting to the ripening stages in Taiwan. In addition, the flowering stage in the second crop season was in November with low temperature period. Therefore, the percentage of methane emission at the flowering stage was lower in the second crop season than that in the first crop season.

Methane emission in the first crop season was only $19-41 \%$ of that in the second crop season. This result was different from the previous studies in the pot cultivation (Yang et al., 1994; Yang and Chang, 1997), and IPCC method (1995). The rice paddy was cultivated with continuously flooded in the pot cultivation and IPCC method, while the rice field was practice with intermittent irrigation from the late booting to the ripening stages.

Methane emission was between 2.6 and $11.7 \mathrm{~g} \mathrm{~m}^{-2}$ in the first crop season, and it was between 13.7 and $28.9 \mathrm{~g} \mathrm{~m}^{-2}$ in the second crop season (Table 1). Using these estimates, total methane emission for the 1996 Taiwan rice crop would range between 4753 and $21,388 \mathrm{Mg}$ for 182,807 ha of paddy rice in the first crop season, and between 22,599 and 47,672 $\mathrm{Mg}$ for 164,955 ha of paddy rice in the second crop season. Annual methane emission from Taiwan paddy fields would be between 27,352 and $69,060 \mathrm{Mg}$. The values were less than that estimated with the IPCC method (total methane emission estimated at 114,167 and $116,980 \mathrm{Mg}$ in the first and the second crop seasons, respectively; annual methane emission estimated at $231,147 \mathrm{Mg}$ ).

\section{Conclusions}

Methane emission and temperature had high values around the mid-day, and low values at the early morning. Methane emission rate was high at the booting and the flowering stages in the first crop season, and high value at the transplanting and the active tillering stages in the second crop season. Total methane emission from rice field in the second crop season was 2-5-fold higher than that in the first crop season with 
intermittent irrigation and this phenomenon was different from that in pot cultivation and IPCC method with continuous flooding system. The correlation coefficient between methane emission rate and temperature was high at the transplanting and the active tillering stages due to the flooding treatment, while the value was low at the flowering and the ripening stages with intermittent irrigation. The percentage of methane emission at the flowering stage ranged from 30 to $43 \%$ of the total amount of methane production in the first crop season and it was only between 1 and $13 \%$ in the second crop season. These phenomena were different from pot cultivation and paddy fields at different areas around the world due to the different irrigation treatments, cropping systems and fertilizer applications. Annual methane emission from Taiwan paddy fields with intermittent irrigation was between 27,352 and $69,060 \mathrm{Mg}$ which was less than $231,147 \mathrm{Mg}$ with IPCC method. Therefore, intermittent irrigation is a very useful strategy for methane mitigation in paddy field.

\section{Acknowledgements}

The authors thank Professors H.C. Lin, Y.S. Wang, R.S. Chung, Ming K. Wang and C.M. Lai for their technical assistance in sampling and helpful comments in preparing this manuscript, the National Science Council of the Republic of China for financial support (NSC 85-2621-P002-016 and NSC 86-2621-P002-004), and the Editor-in-Chief for improvements to the original draft of the paper.

\section{References}

Adhya, T.K., Rath, A.K., Gupta, P.K., Rao, V.R., Das, S.N., Parida, K.M., Parashar, D.C., Sethunathan, N., 1994. Methane emission from flooded rice fields under irrigated conditions. Biol. Fertil. Soils 18, 245-248.

Banker, B.C., Kludze, H.K., Alford, D.P., DeLaune, R.D., Lindau, C.W., 1995. Methane sources and sinks in paddy rice soils: relationship to emissions. Agric. Ecosyst. Environ. 53, 243-251.

Buendia, L.V., Neue, H.U., Wassmann, R., Lantin, R.S., Javellana, A.M., Arah, J., Wang, Z., Wanfang, L., Makarim, A.K., Corton, T.M., Charoensilp, N., 1998. An efficient sampling strategy for estimating methane emission from rice field. Chemosphere 36, 395-407.
Chang, H.L., Yang, S.S., 1997. Measurement of methane emission from soil. Chin. J. Agric. Chem. Soc. 35, 475-484.

Cicerone, R.J., Setter, J.D., Delwiche, C.C., 1983. Seasonal variation of methane flux from a California rice paddy. J. Geophys. Res. 88, 11022-11024.

Crutzen, P.J., 1991. Methane's sinks and sources. Nature 350, 380-381.

Intergovernmental Pannel of Climate Change (IPCC), 1995. Greenhouse gas inventory workbook. In: IPCC Guidelines for National Greenhouse Gas Inventories, vol. 2, 4. 9-4. 21. OECD/IEA, IPCC, UK.

Mah, R.A., Smith, M.R., 1981. The methanogenic bacteria. In: Starr, M.P., Stolp, H., Trüper, H.G., Balows, A., Schlegel, H.G. (Eds.), The Prokaryotes. Springer, Berlin, pp. 948-977.

Nelson, D.W., Sommers, L.E., 1982. Total carbon, organic carbon and organic matter. In: Page, A.L. (Ed.). Methods of Soil Analysis Part 2: Chemical and Microbiological Properties, 2nd edn., Am. Society of Agronomy, Madison, Wisconsin. pp. 539-580.

Neue, H.U., Lantin, R.S., Wassmann, R., Adduna, J.B., Alberto, M.C.R., Andales, M.J.F., 1994. Methane emission from rice soils of the Philippines. In: Minami, K., Mosier, R., Sass, R.L. (Eds.), $\mathrm{CH}_{4}$ and $\mathrm{N}_{2} \mathrm{O}-$ Global Emissions and Controls from Rice Fields and Other Agricultural and Industrial Sources. NIAES Series 2, pp. 55-77, Tokyo, Japan.

Rolston, D.E., 1986. Gas flux. In: Klute, A. (Ed.), Methods of Soil Analysis, 2nd edn., Amer. Soc. Agron. and Soil Sci. Soc. Amer. Monograph No. 9, Wisconsin, USA, pp. 11031119.

SAS Institute, 1988. SAS/STAT User's Guide. Release 6.03 SAS Institute, Cary NC, USA.

Sass, R.L., Fisher, F.M., Tuner, F.T., Jund, M.F., 1991. Methane emission from ice fields as influenced by solar radiation, temperature and straw incorporation. Global Biogeochem.Cycles 5, 335-350.

Schutz, H., Holzapfel-Pschorn, A., Conrad, R., Rennenberg, H., Seiler, W., 1989. A 3-year continuous record on the influence of daytime, season, and fertilizer treatment on methane emission rates from an Italian rice paddy. J. Geophys. Res. 94, 1640516416.

Shin, Y.K., Lee, Y.S., Yun, S.H., Park, M.E., 1995. Methane emission measurement in rice paddy of Korea. The Proceedings of International Symposium on Environment and Biometeorology. China Agricultural Scientech. Press, Beijing, pp. 495-503.

Soil Survey Staff, 1998. Keys to Soil Taxonomy. 8th edn., United States Department of Agriculture and Natural Resources Conservation Service, Washington, D.C.

Taiwan Agricultural Research Institute (TARI), 1978. Soil Survey of Taipei and Ilan Counties. TARI, Taichung, Taiwan.

Wang, M.X., Shangguan, X.J., 1995. Methane emission from rice fields in China. In: Peng, S., Ingram, K.T., Neue, H.U., Ziska, L.H. (Eds.), Climate Change and Rice. Springer, Berlin, pp. 69-79.

Wang, Z.P., DeLaune, R.D., Masscheleyn, P.H., Patrick, W.H. Jr., 1993. Soil redox and $\mathrm{pH}$ effects on methane production in a flooded rice. Soil Sci. Soc. Am. J. 57, 382-385. 
Yagi, K., Minami, K., 1990. Effect of organic matter applications on methane emission from Japanese paddy fields. In: Bouwman, A.F. (Ed.), Soil and the Greenhouse Effect. Wiley, pp. 467-473. Yang, S.S., Chang, E.H., 1997. Effect of fertilizer application on methane emission/production in the paddy soils of Taiwan. Biol. Fertil. Soils 21, 451-456.

Yang, S.S., Chang, E.H., Chung, R.S., Chea, W.P., 1998. Methane production of sediments from lake and river. J. Chin. Agric. Chem. Soc. 36, 111-122.
Yang, S.S., Chang, H.L., 1998. Effect of environmental conditions on methane production and emission of paddy soil. Agric. Ecosys. Environ. 69, 69-80.

Yang, S.S., Lin, C.C., Chang, E.H., Chung, R.S., Huang, S.N., 1994. Effect of fertilizer, soil type, growth season on methane production, and emission in the paddy soils of Taiwan. J. Biomass Energy Soc. China 13, 68-87. 